DOI: $\underline{\text { https://doi.org/10.31933/dijms.v2i1 }}$ Received: 22 July 2020, Revised: 15 August 2020, Publish: 23 September 2020

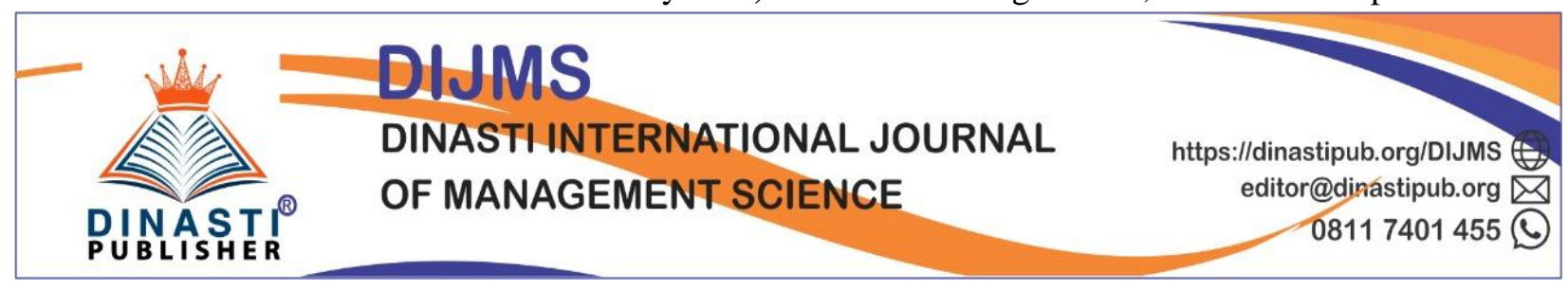

\title{
BUILD OPERATE TRANSFER (BOT) AS BUSINESS ROLE MODEL FOR METERING SYSTEM AND DEVELOPMENT PROJECTS (STUDY CASES ON METERING SYSTEM PROJECT WHICH LOCATED AT PT. REXAUDIA SASADA SENTOSA)
}

\author{
Dicky Andrean ${ }^{1}$, Sugeng Santoso ${ }^{2}$ \\ ${ }^{1}$ Master of Management in Mercu Buana University, Jakarta, Indonesia, dicky.andrean@yahoo.com \\ ${ }^{2}$ Lecturer of Postgraduate in Mercu Buana University, Jakarta, Indonesia, sugeng.santoso@mercubuana.ac.id
}

Corresponding author: first author

\begin{abstract}
This research was carried out on Build Operate Transfer investment in Business cooperation model to metering system development project by examinated those criterias by technology preparedness level (TKT) evaluation method, Innovation preparedness level and political, social economic, technology, environment \& legal aspects (PESTEL). This research was carried out to earned value from level of technological readiness level 8 and 9, Those innovation steady level 3 which involved several division like business development, engineering, accounting \& finance, administration, human resources and health safety environtment officer. Gathered from all divisions and gave an score for TKT 8 assessment should be weight of more than 95\% for accurate data criteria are ready, an assessment of TKT 9 has weight of more than 91\% for technology criteria which tested in actual conditions, an assessment of Katsinov 3 has weighting of more than $94 \%$ for Manufacture Aspects, while assessment of PESTEL has a weight of more than $85 \%$ for Legal Aspect. Furthermore, these assessment results were brought up into focus group discussion by presented the Managing Director as expert judgment on final assessor of data validation, indicators, graphics and risk management planning before making decision about those Build Operate Transfer concept on investment business cooperation model to metering system of development project.
\end{abstract}

Keywords: Build operate transfer, technological readiness level, innovation readiness level. 


\section{INTRODUCTION}

Oil and gas is one of strategic commodities in Indonesia, both as an energy source and as source of foreign exchange of country. Government through Ministry of Energy and Mineral Resources (ESDM) and Special Work Unit for Oil and Gas (SKK Migas) team up with Cooperation Contract Contractor (KKKS) companies and committed to increasing reserves and production of oil and gas. However, according to performance report from Ministry of Energy and Mineral Resources through Directorate General of Oil and Gas regarding the investment target in 2019 on upstream oil and gas industry which not achieved those goal standard from government thats equal to 13.4 Billion US $\$$ and it could be achieved around 12.9 Billion US \$ or $96.35 \%$. Those investment value has not reached target because those investment used for financial exploration activities of US \$ 624 million (6\%), development well activities of US $\$ 1.3$ billion (12\%), production activities of US $\$ 8.1$ billion (74\%) and administrative costs of US \$ 900 million (8\%).
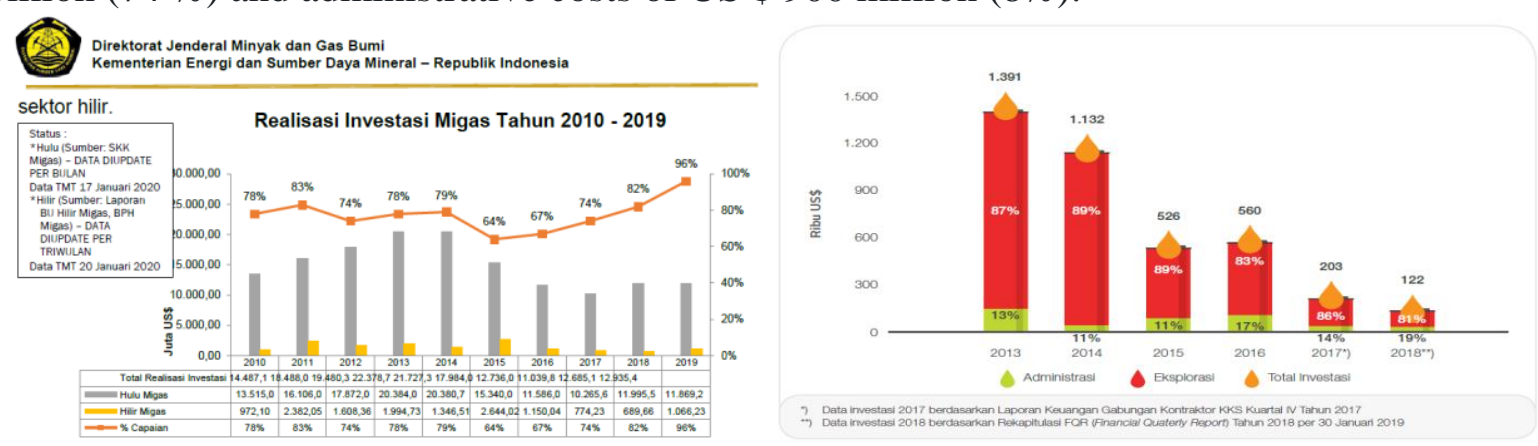

Figure 1. Realization of Upstream Oil and Gas Investment and Comparison of Investment Sources: migas.sdm.go.id and skkmigas.go.id (2019)

These condition of investment climate activities in upstream oil and gas sector has decreased and surfeited, so it needs to be improved and reformed. This condition was strengthened by phenomena that occur on field, such as uncertainty of world oil prices, the Indonesian State which not attractive for investment based on the Fraser Institute Petroleum Survey, those contribution of state revenue from oil and gas industry did not experience that strong increase in 2018, oil and gas resource continue to decline, these saturation in oil and gas exploration activities, continuously in declining oil and gas production capacity, less strict regulations and supervision on oil and gas production and higher cost recovery costs.

Beside those phenomenon above, these total area which covered by metering system from oil and gas block fields in Indonesia was included only in high category of 69 areas or $49 \%$, so those development is needed to support oil and gas production activities in Indonesia. With background of metering systems which not being fulfill, this research was carry out as a form of project models in spreading metering systems.

\section{THEORETICAL REVIEW}

\section{Cooperation Contract Contractor}

Cooperation contract contractor is superintendent of oil and gas production and operations in Indonesia. Based on Government Regulation Number 79 of 2010 which. concern about refundable operating costs and tax treatment of upstream oil and gas business activities that carried out by contractors. These type of cooperation contract used is Production Sharing Contract (PSC) or profit sharing contract with cost recovery method. These amount of value for cost recovery will greatly influence to these reduction and increasing on oil and gas production sharing. 


\section{Public Private Partnership}

According to William J. Parente in (Abbas, 2018) Public Private Partnership or cooperation between Government Agencies and private parties is one of agreement form or contract between public or government sector and private sector/parties which includes several stipulations, such as 1 ) Private parties which carry out government functions for certain period, 2) Private parties would received compensation for these implementation of functions either directly or indirectly and 3) These private party has responsible for risks which arising from holding of these function.

\section{Build Operate Transfer}

From several forms of Public Private Partnership cooperation which often carried out in Indonesia are Build-Operate-Transfer (BOT), where the private sector as an investor carries out infrastructure development, operates and carries out maintenance of facilities that has been built and returns to government after contract period expires in time that have been specified. According to Puspitasari and Santoso (2018) BOT is form of cooperation between government and private sector, in which government has an authorizes towards private party to finance those construction, operation and maintenance and accumulate those fees from building's users during agreed time period, then these building would returned to the government.

\section{Focus Group Discussion}

Focus Group Discussion according to Kitzinger and Barbour (1994) is an exploration of particular issue/phenomenon from an individual group discussion that focuses on joint activities among the individuals which involved in it and earned mutual agreement. Meanwhile based on Bisjoe (2018) FGD is systematic process from gathering data and information detail about specific problem through group discussion. Lambert and Loiselle (2008) further said that FGD method used as a method to gained data / information about products through social interactions from group of individuals who in it, fellow individuals has an influence to one another.

\section{PESTEL Analysis Method}

One of comprehensive method that used to assessment industry it could be use PESTEL Aspect analysis (Kolinos \& Read in Kara, 2018) namely: 1) political aspects which include various aspects that support economic growth, 2) economic aspects seen from strength of different currencies differences, inflation rates, money market interest rates and tax laws, 3) social aspects including culture, demographics, education and other social influences, 4) technological aspects which consist of technology and information development to improve technology that related to industry and marketing, 5) environment aspects including ecological issues, changes in weather cycles, disposal of residual waste, etc. 6) related to legal aspects regarding consumers and competition between businesses, health and safety laws, and labor-related regulations.

\section{Technology Readiness Level}

Technology Readiness Level is level of maturity condition or preparedness of particular technological research and development systematically that measured with aim of capability to adopted by users from government sector, industry players, private parties and 
the public. Measurement of Technology Readiness Level (TKT) should be carried out by technology result from research and development activities which funded by government budget or collaboration with government. (Wardana, et., Al., 2020).

\section{Innovation Readiness Level}

Innovation readiness level known as Katsinov is a method that could estimate innovation readiness from an innovation program both companies, research and development institutions and universities which could be seen from several aspects, such as technology, market, organization, partnership, manufacture, risk and investment.

\section{RESEARCH METHODS}

This research used mix method research method which qualitative supported by quantitative data. Research with qualitative approach was carried out through questionnaires and interviews, focus group discussions and decision making by presented expert judgment namely Managing Director of PT. Rexaudia Sasada Sentosa. This research was conducted with exploratory type that aimed to management control.

In this research, the subjects used is division of administration \& human resources department, accounting \& finance, engineering, health safety environment, business development. The object under this research was Technology Readiness Level (TKT) criteria, Innovation Readiness Level (Katsinov) and PESTEL aspects that influence scores of BOT as an investment business cooperation model to metering system development projects.

Research population is coorperation contracts contractor companies in oil and gas industry throughtout Indonesia. Based on this research it used non-probability sampling method with accidental sampling technique, researcher took a sample that encountered, namely existence of build operate transfer investment business cooperation model that was carried out at PT. Rexaudia Sasada Sentosa to Metering System Technology Development Project.

Data collection techniques used in primary data through questionnaires, interviews, technology feasibility analysis, and expert judgment. Data analysis methods here on research was processed and tested those validity and reliability from internal questionnaire data that was taken and continued with method that evaluated aspects and criteria based on questionnaire and proceed to focus group discussions represented by Head of Division as representatives from company management and presented Managing Director as expert judgment to know about perceptions, opinions, beliefs and attitudes towards build operate transfer investment business on cooperation model to metering system development project at PT. Rexaudia Sasada Sentosa.

These assessment method used aspects of PESTEL (Political, Economic, Social, Technology, Environment \& Legal), Technology Readiness Level criteria (TKT) and Innovation Readiness Level Criteria (Katsinov) as an assessment indicators.

\section{RESULTS AND DISCUSSION Validity and Reliability Test}

In this research, these examined was discovered and sized up by Bivariate Pearson correlation with an error tolerance level of $5 \%$ and $r$ table value of 0.3233 . Based on these validity test results of it shows that all the values of $r$ count tabel $r$ tables of the criteria so that it can be concluded that all criteria are valid. 
Table 1. Validity Test Results

\begin{tabular}{cccc}
\hline Criteria & r table & r count & Information \\
\hline A1 & 0,3233 & 0,483 & Valid \\
\hline A2 & 0,3233 & 0,360 & Valid \\
\hline A3 & 0,3233 & 0,442 & Valid \\
\hline A4 & 0,3233 & 0,375 & Valid \\
\hline A5 & 0,3233 & 0,544 & Valid \\
\hline A6 & 0,3233 & 0,429 & Valid \\
\hline A7 & 0,3233 & 0,467 & Valid \\
\hline A8 & 0,3233 & 0,444 & Valid \\
\hline A9 & 0,3233 & 0,406 & Valid \\
\hline A10 & 0,3233 & 0,548 & Valid \\
\hline A11 & 0,3233 & 0,513 & Valid \\
\hline A12 & 0,3233 & 0,559 & Valid \\
\hline A13 & 0,3233 & 0,513 & Valid \\
\hline A14 & 0,3233 & 0,388 & Valid \\
\hline A15 & 0,3233 & 0,642 & Valid \\
\hline A16 & 0,3233 & 0,419 & Valid \\
\hline A17 & 0,3233 & 0,420 & Valid \\
\hline A18 & 0,3233 & 0,369 & Valid \\
\hline A19 & 0,3233 & 0,492 & Valid \\
\hline A20 & 0,3233 & 0,424 & Valid \\
\hline A21 & 0,3233 & 0,333 & Valid \\
\hline A22 & 0,3233 & 0,512 & Valid \\
\hline A23 & 0,3233 & 0,329 & Valid \\
\hline
\end{tabular}

These reliability test method used Cronbach's alpha. According to reliability test results, it shows that as many as 23 of research criteria have a Cronbach's alpha coefficient of 0.816 so that it can be declared reliable.

Table 2. Reliability Test Results

\begin{tabular}{ccc}
\hline Cronbach's Alpha & $\begin{array}{c}\text { Cronbach's Alpha Based on } \\
\text { Standardized Items }\end{array}$ & N of Items \\
\hline, 816 &, 825 & 23 \\
\hline
\end{tabular}

\section{Assessment of Aspects and Criteria}

Evaluation from aspects and criteria as indicators was done by calculating the mean value from the acquisition of scores in questionnaire. Here are those results from technology level treshold point.

Table 3. Treshold Point Technology

\begin{tabular}{cccc}
\hline Level & Criteria Amount & Theshold Point Minimum & Respondent \\
\hline TKT 9 & 8 & $80 \%$ & 25 \\
\hline TKT 8 & 10 & $80 \%$ & 25 \\
\hline
\end{tabular}

\section{Sizing of Technology Readiness Level}

This research application was carried out from metering system development project at PT. Rexaudiax Sasada Sentosa. Technology Readiness Level from this research regarding metering system development projects which carried out at the level: TKT Level 8, namely development of the metering system project, and TKT Level 9, namely the implementation of metering system development projects in Indonesia. In these assessment result from total questionnaire of respondents towards Technology Readiness Level or Technology Admission (TKT) Levels 8 which earned by IBM SPSS calculation as its follows: 


\section{Table 4. TKT Calculation Level $8^{\text {th }}$ Results}

\begin{tabular}{|c|c|c|c|c|c|c|c|c|c|c|c|}
\hline & & $\begin{array}{c}\text { Bentuk, } \\
\text { kesesuaian } \\
\text { dan fungsi } \\
\text { komponen } \\
\text { kompatibel } \\
\text { dengan } \\
\text { sistem } \\
\text { operasi. } \\
\end{array}$ & $\begin{array}{l}\text { Mesin dan } \\
\text { peralatan } \\
\text { telah diuji } \\
\text { dalam } \\
\text { lingkungan } \\
\text { produksi. }\end{array}$ & $\begin{array}{l}\text { Diagram } \\
\text { akhir } \\
\text { selesai } \\
\text { dibuat. }\end{array}$ & $\begin{array}{c}\text { Proses } \\
\text { fabrikasi } \\
\text { diujicobakan } \\
\text { pada skala } \\
\text { percontohan } \\
\text { (pilot-line } \\
\text { atau LRIP) }\end{array}$ & $\begin{array}{c}\text { Uji proses } \\
\text { fabrikasi } \\
\text { menunjukkan } \\
\text { hasil dan } \\
\text { tingkat } \\
\text { produktivitas } \\
\text { yang dapat } \\
\text { diterima. } \\
\end{array}$ & $\begin{array}{l}\text { Uji seluruh } \\
\text { fungsi } \\
\text { dilakukan } \\
\text { dalam } \\
\text { simulasi } \\
\text { lingkungan } \\
\text { operasi. }\end{array}$ & $\begin{array}{c}\text { Semua bahan } \\
\text { atau material } \\
\text { dan peralatan } \\
\text { tersedia untuk } \\
\text { digunakan } \\
\text { dalam } \\
\text { produksi. }\end{array}$ & $\begin{array}{c}\text { Sistem } \\
\text { memenuhi } \\
\text { kualifikasi } \\
\text { melalui test } \\
\text { dan evaluasi } \\
\text { (DT\&E } \\
\text { selesai), dan }\end{array}$ & $\begin{array}{l}\text { Data yang } \\
\text { akurat } \\
\text { telah siap }\end{array}$ & $\begin{array}{c}\text { Siap untuk } \\
\text { produksi } \\
\text { skala penuh } \\
\text { (kapasitas } \\
\text { penuh) }\end{array}$ \\
\hline \multirow[t]{2}{*}{$\mathrm{N}$} & Valid & 25 & 25 & 25 & 25 & 25 & 25 & 25 & 25 & 25 & 25 \\
\hline & Missing & 0 & 0 & 0 & 0 & 0 & 0 & 0 & 0 & 0 & 0 \\
\hline \multicolumn{2}{|c|}{ Mean } & 3,96 & 3,80 & 3,64 & 3,44 & 3,68 & 4,16 & 4,68 & 4,80 & 4,84 & 4,68 \\
\hline \multicolumn{2}{|c|}{ Std. Deviation } & .676 & .707 &, 700 &, 712 & .627 & .473 & 627 & .408 & .374 & .627 \\
\hline \multicolumn{2}{|c|}{ Minimum } & 3 & 3 & 3 & 2 & 3 & 3 & 3 & 4 & 4 & 3 \\
\hline \multicolumn{2}{|c|}{ Maximum } & 5 & 5 & 5 & 5 & 5 & 5 & 5 & 5 & 5 & 5 \\
\hline \multicolumn{2}{|c|}{ Sum } & 99 & 95 & 91 & 86 & 92 & 104 & 117 & 120 & 121 & 117 \\
\hline
\end{tabular}

Whilst these results of total questionnaire assessment from respondents regard Technology Readiness Level or Technology Readiness Level 9 which earned by IBM SPSS calculation as its follows:

Table 5. TKT Calculation Level $9^{\text {th }}$ Results

\begin{tabular}{|c|c|c|c|c|c|c|c|c|c|}
\hline & & $\begin{array}{c}\text { Konsep } \\
\text { operasional } \\
\text { telah benar - } \\
\text { benar dapat } \\
\text { diterapkan. }\end{array}$ & $\begin{array}{l}\text { Perkiraan } \\
\text { investasi } \\
\text { teknologi } \\
\text { sudah } \\
\text { dibuat. }\end{array}$ & $\begin{array}{c}\text { Tidak ada } \\
\text { perubahan } \\
\text { desain yang } \\
\text { signifikan. }\end{array}$ & $\begin{array}{c}\text { Teknologi } \\
\text { telah teruji } \\
\text { pada } \\
\text { kondisi } \\
\text { sebenarnya. }\end{array}$ & $\begin{array}{c}\text { Produktivitas } \\
\text { pada tingkat } \\
\text { stabil. }\end{array}$ & $\begin{array}{c}\text { Semua } \\
\text { dokumentasi } \\
\text { telah } \\
\text { lengkap. }\end{array}$ & $\begin{array}{l}\text { Estimasi harga } \\
\text { produksi } \\
\text { dibandingkan } \\
\text { kompetitor, dan }\end{array}$ & $\begin{array}{l}\text { Teknologi } \\
\text { kompetitor } \\
\text { diketahui }\end{array}$ \\
\hline \multirow[t]{2}{*}{$\mathrm{N}$} & Valid & 25 & 25 & 25 & 25 & 25 & 25 & 25 & 25 \\
\hline & Missing & 0 & 0 & 0 & 0 & 0 & 0 & 0 & 0 \\
\hline \multicolumn{2}{|c|}{ Mean } & 4,16 & 4,12 & 4,24 & 4,76 & 3,68 & 4,68 & 4,68 & 3,24 \\
\hline \multicolumn{2}{|c|}{ Std. Deviation } & 473 & 666 &, 523 & 436 & 627 & .476 & .557 & 1,234 \\
\hline \multicolumn{2}{|c|}{ Minimum } & 3 & 3 & 3 & 4 & 3 & 4 & 3 & 1 \\
\hline \multicolumn{2}{|c|}{ Maximum } & 5 & 5 & 5 & 5 & 5 & 5 & 5 & 5 \\
\hline \multicolumn{2}{|c|}{ Sum } & 104 & 103 & 106 & 119 & 92 & 117 & 117 & 81 \\
\hline
\end{tabular}

From these Calculation result from Technology Level 8th and 9th, these following assessment that obtained, such as:

1) These average rating scale (mean) at TKT Level 8 \& Level 9 there has none TRI value below 2.90 so it could be categorized as technological readiness level on high.

2) On Level 8 TKT survey criteria "The fabrication process was tested on a pilot scale" has the smallest average (Mean) of 3.44, it could be describe that after Reseacrh and Development process done it was continued to examined process which involving independent institutions and respondent was not involved in this process so these assessment given by respondent was categorized as quite important to know from results of test.

3) In Level 9 TKT survey criteria "Competitor technology is known" has smallest average (Mean) of 3.24 it could be ilustrated that these assessment due to flow meter technology that will be applied on investment business cooperation model in metering system development project still new and not yet known in detail by respondents.

\section{Sizing of Innovation Readiness level}

Data processed in form of questionnaire answers from respondents by any divisions in company. From these assessment results by these total questionnaire of respondents for Innovation Readiness Level on Level 3 (Katsinov) it was obtained an assessment as in belows:

1) These average rating scale (mean) at Katsinov Level 3 does not have a TRI value below 2.90 so it could be categorized that innovation readiness level based on technology at peak level. 
2) In Katsinov Level 3 survey criteria "The actual system of technology has been demonstrated based on fact in environment" has an average value of 3.40. these development of metering system is still new and has not been known in detail by respondents.

3) In Katsinov Level 3 survey criteria "Having further detailed about division of responsibilities and workloads" has an average value of 3.44 it could be seen that assessment in metering system development project which carried out these delegation process and divide the tasks is done in every stages to get work process which has maximum and effective so it requires controlling and assisting to new engineer both processing technical data, drawing, calculation and project documentation. This also in line with Katsinov Level 3 survey criteria "Identification of some additional staff needed" which has an average value of 3.65 so it could be assessed that workload and responsibility for metering system development project requires additional staff in development of project organization structure to support those distribution of tasks to be more organized and efficient in achieving company targets.

These comparison of Katsinov Level 3 assessments could be explained from divisions in company that could be seen in table below.

Table 6. Comparison of Assessment Levels of KATSINOV Level 3

\begin{tabular}{|l|c|c|c|c|}
\hline \multicolumn{1}{|c|}{ Aspek } & Mean_Administration, HRD, HSE & Mean_Business Development & Mean_Accounting \& Finance & Mean_Engineering \\
\hline Technology & $85,92 \%$ & $82,44 \%$ & $80,91 \%$ & $77,87 \%$ \\
\hline Market & $86,64 \%$ & $84,98 \%$ & $80,00 \%$ & $82,22 \%$ \\
\hline Organization & $77,50 \%$ & $81,26 \%$ & $78,84 \%$ & $78,66 \%$ \\
\hline Manufacture & $91,64 \%$ & $88,13 \%$ & $98,30 \%$ & $94,81 \%$ \\
\hline Investment & $93,30 \%$ & $88,23 \%$ & $90,86 \%$ & $92,48 \%$ \\
\hline Partnership & $87,18 \%$ & $89,86 \%$ & $87,18 \%$ & $93,23 \%$ \\
\hline Risk & $65,00 \%$ & $79,96 \%$ & $70,00 \%$ & $78,88 \%$ \\
\hline
\end{tabular}

\section{Internal Assessment Uses PESTEL Aspects}

From assessment result of total internal questionnaire to scoring those investment business model by parameters PESTEL (Political, Economic, Social, Technology, Environment \& Legal) of respondents which obtained from these following assessment:

1) These average rating scale on majority of internal surveys has value above 3 which considered logical.

2) On internal survey criteria "Having a domestic component" has an average value of 3.59, it can be ilustrated that these assessment occurs because on investment business cooperation model apps which used to metering system development project still using importing materials which is flow meter component while component in domestic country is a fabrication process that uses local pipeline material, engineering design, calculation and local labor as part of domestic component count.

3) On internal survey criteria "Having a risk control plan at stage of applying technology" has an average value of 3.78 , so it could be seen that these assessment occurs because these engineering design from metering system still requires supervision of principle in configuration, integration, adjustment settings and standard operating procedure in operational pattern of metering system. Therefore technical factors in controlling risk for the use of flow meter technology could be identified properly. 


\section{Comparison of Internal Values against Aspects of PESTEL}

From these comparison result that obtained variations from assessment of each division aspects of PESTEL to evaluated Build Operate Transfer investment business cooperation model in metering system development project.

Table 7. Comparison of Internal Assessments Against Aspects of PESTEL

\begin{tabular}{|l|c|c|c|c|}
\hline Aspek & Mean_Administration, GA, HSE & Mean_Business Development & Mean_Accounting \& Finance & Mean_Engineering \\
\hline Politic & $81,2 \%$ & $83,1 \%$ & $82,4 \%$ & $81,6 \%$ \\
\hline Economic & $81,6 \%$ & $79,8 \%$ & $85,0 \%$ & $81,4 \%$ \\
\hline Social & $81,6 \%$ & $79,9 \%$ & $83,2 \%$ & $76,0 \%$ \\
\hline Technology & $86,0 \%$ & $83,0 \%$ & $80,0 \%$ & $83,5 \%$ \\
\hline Environment & $84,9 \%$ & $87,3 \%$ & $77,5 \%$ & $81,5 \%$ \\
\hline Legal & $89,9 \%$ & $86,2 \%$ & $92,3 \%$ & $85,5 \%$ \\
\hline
\end{tabular}

\section{Discussion}

Technological readiness level (TKT) and innovation readiness level (Katsinov) is a structure system measure to understand these technological maturity so result from technological development is ready to be applied and integrated as an innovation and ready to be commercialized. On metering system development project, an assessment method using TKT criteria used as critical success factor for product technology development. The higher TKT level, the greater chances of successful product on development program, system examination and operation on actual application.

Whereas these evaluation method used Katsinov BOT criteria as a business cooperation model to metering system development project Katsinov method could be used to increase these commercial value of technology applications used.

To discovered if BOT as an investment business cooperation model to metering system development project according to assessment result and weighting of respondents at company PT. Rexaudia Sasada Sentosa, with an assessment of TKT 8 criteria "Accurate data is ready" and the TKT 9 criteria which is "Technology has been tested in actual conditions" made an important component to metering system development project at PT. Rexaudia Sasada Sentosa.

Whereas these assessment using Katsinov method of Manufacturing and Investment aspects is an important component based on assessment result and weighting of respondents in Build Operate Transfer (BOT) as a model of investment business cooperation to metering system development project.

These ways could be done by PT. Rexaudia Sasada Sentosa in assessing these criteria for TKT 8 and 9, Katsinov's criteria and aspects of the PESTEL are:

1) On selecting process of investment business cooperation models, an assessment from aspects which has most influences is needed.

2) On Build Operate Transfer project the development of metering system requires data and technical advisors from manufacture as readiness for technology application to system which tested through those successful operation.

3) On metering system technology industry, Those Research \& Development (R\&D) continues developt to technological innovation processed, so data technology features are needed by competitors, then PT. Rexaudia Sasada Sentosa could develop concepts, design applications for flow meter technology to metering systems.

4) In flow meter technology for fabrication process, PT. Rexaudia Sasada Sentosa requires visit to its production, examine and certification facilities so they could evaluated directly at Technology Readiness Level (TKT). 
5) Build Operate Transfer (BOT) on investment business cooperation model to metering system development project has strongly influenced by fluctuations in Indonesian economy, changes in world oil prices then Innovation Readiness Level (Katsinov) method. Which consider from PT. Rexaudia SasadaSentosa is a risk factor.

6) Build Operate Transfer as an investment business cooperation model based on assessment of PESTEL aspects, the legal aspect (Legal) is highest weighting assessment that should be considered so that those investment business cooperation model can be divided into risks and have a legal basis in cooperation contract.

\section{CONCLUSION AND SUGGESTIONS Conclusion}

Based on these analysis results that authors have done, it could be concluded:

1) From these measurements result and analysis by Technology Readiness Level the Level 8 has criteria "Accurate data is ready" with highest assessment point because Flow Meter technology has been tested and received certification and used as part of planning, database on Metering System development project. And Technology Readiness Level (TKT) Level 9 with these criteria "Technology has been tested in actual conditions" has highest point because of these result certification by an independent institution for accuracy value and could be function well on metering system development projects.

2) From these calculations result and analysis using these Innovation Readiness Level or on Level 3 (Katsinov) Level 3 has highest point such as in Manufacture (Mf) aspect which has an important role for company to scoring the use of proven technology through operational success in metering system development projects. And results from estimates and analysis by PESTEL aspect have highest rating in legal aspect (legal) to carrying out strategic planning in business model of Build Operate Transfer investment business.

3) Based on these analysis results and discussing those results from Developing Question assessment in focus group discussions and by listening to opinions from Expert Judgment in BOT decision making as a business cooperation model to metering system development project is a new investment business cooperation model which has one of benefit factors which has shorter work hours that will be carried out by PT. Rexaudia Sasada Sentosa.

\section{Suggestions}

From these research result which has been done and several analysis about discussion and conclusions above, the suggestions that could be drawn as its follows:

1) Evaluating criteria for technology readiness (TKT) to accurate data is ready to be supported by need for form, comformity and components compatible function with operating system as final assessment of BOT as form of business cooperation to metering system development project.

2) Those evaluation criteria for Innovation Readiness level (Katsinov) on Manufacture aspects was required these cooperation by involving Technical Experts as Advisors who help to implemented those technology which well integrated to metering system development projects to be commercialized.

3) Those hopes from author to next further research that they could be measure these Technology Readiness Level criteria alongside Innovation Readiness level as well as PESTEL aspects in evaluating these investment business cooperation models in other industrial sectors related to development of new technologies that still require experimentation, refinement and continuous experiments so they could succeed these 
implemented and enhanced and integrated as product innovation program results from research and development which has been produced and deployed to the use of new technology which ready to enter to market and survive and continuing there.

\section{REFERENCES}

Abbas, Moeh. Yafie. (2018). Public Private Partnership Dalam Pembangunan dan Pengelolaan Suncity Plaza Sidoarjo (Model Perjanjian Build Operate Transfer antara Pemerintah Kabupaten Sidoarjo dengan PT. Indraco. Kebijakan dan Manajemen Publik, 6(3):1-9.

Peraturan Pemerintah Republik Indonesia. (2010). Peraturan Pemerintah Republik Indonesia Nomor 79 Tahun 2010 Tentang Biaya Operasi yang dapat di Kembalikan dan Perlakuan Pajak Penghasilan di Bidang Usaha Hulu.

Puspitasari, Ikka and Budi Santoso. (2018). Perjanjian Kerjasama Pemerintah Dan Swasta Dengan Pola (Bot) Build Operate Transfer Dalam Pembangunan Jalan Tol (Studi Pembangunan Jalan Tol Semarang-Solo), Junal Law Reform, 14(1): 57-73.

Peraturan Pemerintah Republik Indonesia. (2019). Peraturan Menteri Riset, Teknologi, dan Pendidikan Tinggi Republik Indonesia Nomor 29 Tahun 2019 Tentang Pengukuran Dan Penetapan Tingkat Kesiapan Inovasi.

Peraturan Pemerintah Republik Indonesia. (2019). Peraturan Menteri Riset, Teknologi, dan Pendidikan Tinggi Republik Indonesia Nomor 42 Tahun 2016 Tentang Pengukuran Dan Penetapan Tingkat Kesiapterapan Teknologi.

Kitzinger, Jenny. (1994). The methodology of Focus Groups: the importance of interaction between research participants, Sociol. Health Illness, 16( 1):103-121.

Bisjoe, Achmad Rizal H. (2018). Menjaring Data Dan Informasi Penelitian Melalui FGD. Info Tek. Eboni, 15(1):17-28.

Lambert, S. D., \& C. G. Loiselle. (2008). Combining individual interviews and focus groups to enhance data richness, J. Adv. Nurs., 62( 2):228-237.

Kara, E. (2018). A Contemporary Approach For Strategic Management in Tourism Sector: PESTEL Analysis on The City Muğla, Turkey. J. Bus. Res. - Turk, 10(2):598-608.

Wardana, M. Fadhil Kusuma, Syifa Nida Azzahra, dan Bunga Rizki Ulfira. (2020). Antologi Karya Perpajakan Sebuah Pembahasan Mahasiswa Jurusan Pajak. Yogyakarta: Deepublish. 